\title{
CARRIER DETECTION OF DUCHENNE AND BECKER MUSCULAR DYSTROPHY USING MUSCLE DYSTROPHIN IMMUNOHISTOCHEMISTRY
}

\author{
ACARY S. BULLE OLIVEIRA * - ALBERTO A. GABBAI* - BENY SCHMIDT ** \\ BEATRIZ HITOMI KIYOMOTO * - J. G. CAMARGO LIMA * \\ CARLO MINETTI *** - EDUARDO BONILLA ***
}

\begin{abstract}
SUMMARY - To ascertain whether dystrophin immunohistochemistry couldimprove DMD/ B MD carrier detection, we analyzed 14 musclebiopsies from 13 D D and one B M probable and possible carriers. All women were also evaluated using conventional methods, including genetic analysis, clinical and neurological evaluation, serum CK levels, KMg, and muscle biops. In 6 cases, there wias a mosaic of dystrophin-positive and dystrophin-deficient fibers that allowed to make the diagnosis of a carrier state. Comparing dystrophin immunohistochemistry to the traditional methods, it was noted that this method is less sensitive than serum CK

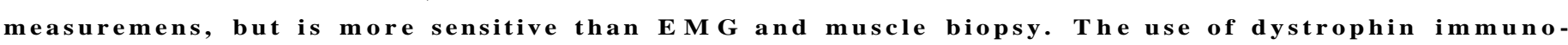
histochemistry in addition to CK, E1MG and muscle biopsy improved the accuracy of carrier detection. This method is (also helpful to distinguish manifesting Do carriers from patients with other neuromuscular diseases like limb-girdle muscular dystrophy and spinal muscular atrophy.
\end{abstract}

K E Y WORDS: muscular dystrophy (Duchenne and Becker), carrier detection, dystrophin.

Detecção de portadora» de distrofia muscular de Duchenne e de Becker utilizando imuno-hi*toquímica com distrofina

RESUMO - Para determinar se imuno-histoquímicia com distrofina poderia melhorar a detecção de portadoras de distrofia muscular de Duchenne (DMD) e de Becker (DMB), analisamos 14 biópsias musculares de 13 portadoras prováveis ou possíveis de DMD e de urna portadora provável de DMB. Todas as mulheres foram também avaliadas usando métodos convencionais, incluindo análise genética, avaliação clínica e neurológica, níveis séricos de CK, EMG e biópsia muscular com estudo histoquímico. Em 6 casos havia um mosaico de fibras musculares distrofina-positivas e distrofina-negativas, que permitia caracterizai* um estado de portadora. Comparando imuno-histoquímica com distrofina e métodos tradicionais, notou-se que este método é menos sensível que medidas de CK, mas é mais sensível que EMg e biópsia muscular. O uso deste método associado a CK, EMG e biópsia muscular aumentou ta possibilidade de deteç̧ão de portadoras. Este método é também útil para distinguir portadoras manifestantes de $D M D$ de pacientes com outras doenças neuromuseulares como a distrofia cintura-membros e amiotrofia espinhal progressiva,

PALAVRAS-CHAVE: distrofia muscular (Duchenne e Becker), deteç̧ãode portadoras, distrofina.

* Departement of Neurology, Neurosurgery and Experimental Neurology of Escola Ftaulista de Medicina (EPM), São Paulo; **Adjunct Professor, Department of Pathology, EPM; *** Department of Neurology, College of Physicians and Surgeons of Columbia University, New York. Supported partially by the Brazilian Research Council (CNPq).

Dr. Acary Soum Bulle Oliveira - Disciplina de Neurologia, Escola Paulista de Medicina Rua Botucatu 762 - 04028 São Paulo SP - Brasil. 
The detection of Duchenne (DMD) and Becker (BMD) muscular dystrophy carriers is one of the major goals in the prevention of these diseases. Traditional methods of carrier detection have a low sensitivity and are not specific Analysis of family pedigrees, neurological evaluation, serum creatine kinase (CK) levels, eleetromyogram (EMG), and muscle biopsy, alone or in combination, lead to a maximum $80 \%$ accuracy ${ }^{2}$. Although highly specific, DNA analysis to detect deletions in the dystrophin gene has not $100 \%$ sensitivity

To evaluate the sensitivity of dystrophin immunohistochemistry, we studied 14 possible and probable carriers of DMD and BMD in combination with the other traditional methods.

\section{PATIENTS AND METHODS}

We studied 14 women, 3 probable and 11 possible DMD (only one a BMD) carriers, aged 6 to 37 years. Thei diagnosis of DMD and BMD in the affected members of tho families, was made according to established criteria 4.

Probable carrier was. defined as a woman with two or more affected sons. Possible carrier was defined as a woman with only one affected son and no other male affected in her fiamily; or a woman without affected son but with affected male(s) in her family 9. Manifesting carrier (or symptomatic carrier) was defined as a carrier with proximal muscle weakness.

All carriers were examined neurologically including a manual muscle test 7, most of them on several occasions. Laboratory tests included electrocardiogram (ECG), serum CK levels, EMG, and muscle biopsy with histochemistry and dystrophin immunostain.

Muscle biopsies were frozen in liquid nitrogen and processed according to standard criteria 3. For immunohistochemistry, the muscle samples were processed by one of us (EB), in New York, following a previously published technique

\section{RESULTS}

The clinical history, genetic aspects, clinical manifestations and neurological examination of the 14 patients are summarized in Table 1. Cases 3 and 5 with proximal limb weakness were manifesting' carriers of DMD. Case 14 was a BMD carrier.

ECG, EMG, muscle biopsy results and serum CK levels are summarized in Table 2.

Immunohistochemistry with dystrophin was performed in all 14 women.

Normal immunostaining of the muscle fibers (a thin and continuous layer of immunofluorescence at the sarcolemma of the fibers) was seen in 8 (cases 6, 7, 8, 9, 10, 11, 12 and 13) (Fig. 1).

In 8 muscle, biopsies (cases. 1, 2, 3, 4, 5 and 14) the dystrophin immunostaining pattern was altered evidencing a deficiency of dystrophin at the sarcolemma either in groups cr in isolated muscle fibers. In these same patients there remained, nonetheless, a population of fibers that showed a normal immunostaining. Comparing serial sections stained with ATPase 9.4, it was seen that the immunostaining abnormalities were randomly distributed not particularly associated to either type I or II fibers.

The three cases of asymptomatic carriers (cases 1, 2 and 4) showed lack of immunostaining in muscle fibers isolatedly disposed (Fig. 2). The two cases of manifesting carriers of DMD (cases 3 and 5) and the asymptomatic BMD carrier showed a marked reduction in the immunostaining at the sarcolemma of fibers, with immunostaining reduced in groups of muscle fibers (Fig. 3).

Two (cases 5 and 14) of the 6 cases with abnormal immunostaining were probable carriers and 4 (cases 1, 2, 3 and 4) were possible carriers. The immunostaining aspect in case 3, a possible carrier, was indistinguishable from that seen in the two probable carriers (cases 5 and 14). These cases showed lack of immunostaining in groups of muscle fibers. The other three cases (cases 1, 2 and 4) possible carriers showed lack of immunostaining in a few isolated muscle fibers.

Comparison of the results among the different diagnostic methods - In Tables 3 to 5 are shown the results amongj the different methods. In Tables $6(a, b$, c, d, e) are matched the results of immunohistochemistry with dystrophin with the traditional methods in the 14 cases. 
Table 1. Clinical history, genetic aspects, clinical manifestations and neurological examination in 14 cases.

\begin{tabular}{|c|c|c|c|c|}
\hline Case & $\begin{array}{c}\text { Age at } \\
\text { examination } \\
\text { (years) }\end{array}$ & Symptoms & $\begin{array}{c}\text { Genetic } \\
\text { carrier } \\
\text { risk }\end{array}$ & $\begin{array}{l}\text { Neurological } \\
\text { exam }\end{array}$ \\
\hline 1 & 37 & ndn & $\mathrm{pp}$ & $\mathrm{nl}$ \\
\hline 2 & 30 & ndn & $\mathrm{pp}$ & nl \\
\hline 3 & 11 & weakness & $\mathrm{pp}$ & $\begin{array}{l}\text { lumbar lordosis } \\
\text { calf enlargement } \\
\text { prox. weiakness }\end{array}$ \\
\hline 4 & 29 & ndn & $\mathrm{pp}$ & $\mathrm{nl}$ \\
\hline $\mathbf{5}$ & 34 & weakness & $\mathrm{p}$ & $\begin{array}{l}\text { lumbar lordosis } \\
\text { calf enlargement } \\
\text { prox. weakness }\end{array}$ \\
\hline 6 & 12 & ndn & $\mathrm{pp}$ & $\mathrm{nl}$ \\
\hline 7 & 31 & ndn & $\mathrm{pp}$ & $\mathrm{nl}$ \\
\hline 8 & 33 & ndn & $\mathrm{pp}$ & $\mathrm{nl}$ \\
\hline 9 & 28 & ndn & $\mathrm{pp}$ & $\mathrm{nl}$ \\
\hline 10 & 37 & $n d n$ & p & nl \\
\hline 11 & 34 & fatigability & $\mathrm{pp}$ & calf enlargement \\
\hline 12 & 7 & cramps & pp & calf enlargement \\
\hline 13 & 35 & ndn & $\mathrm{pp}$ & $\mathrm{nl}$ \\
\hline 14 & 35 & ndn & $\mathrm{p}$ & calf enlargement \\
\hline
\end{tabular}

p, probable carrier; pp, possible carrier; nl, normal; ndn, nothing to note.

Table 2. The electrocardiograms, serum CK levels, eletromyograms and muscle biopsy of the 14 cases.

\begin{tabular}{|c|c|c|c|c|}
\hline Case & ECG & $\begin{array}{c}\mathrm{CK} \\
(\mathrm{UI} / \mathrm{L})\end{array}$ & EMG & Muscle biopsy \\
\hline 1 & $\mathrm{nl}$ & $80 / 107 / 90$ & $\mathbf{M}$ & $\begin{array}{l}\text { necrosis } \\
\text { hyaline degeneration }\end{array}$ \\
\hline 2 & $\mathrm{nl}$ & $33 / 45 / 40$ & $\mathrm{nl}$ & fibers type IIb \\
\hline 3 & $\begin{array}{c}\text { sinusal } \\
\text { arrhythmia }\end{array}$ & $920 / 1514 / 1010$ & $\mathbf{M}$ & $\begin{array}{l}\text { necrosis } \\
\text { hyaline degeneration } \\
\text { connective tissue }\end{array}$ \\
\hline 4 & $\mathrm{nl}$ & $70 / 82 / 75$ & nl & $\begin{array}{l}\text { disproportion of } \\
\text { type I and II fibers }\end{array}$ \\
\hline 5 & n] & $120 / 184 / 130$ & $\mathbf{M}$ & $\begin{array}{l}\text { necrosis } \\
\text { hyaline degeneration }\end{array}$ \\
\hline 6 & $\mathrm{nl}$ & $28 / 107 / 60$ & nl & $\mathrm{nl}$ \\
\hline 7 & $\mathrm{nl}$ & $30 / 25 / 35$ & $\mathrm{nl}$ & $\mathrm{nl}$ \\
\hline 8 & $\mathrm{nl}$ & $21 / 35 / 20$ & $\mathrm{nl}$ & $\mathrm{nl}$ \\
\hline 9 & $\mathrm{nl}$ & $16 / 30 / 20$ & $\mathrm{nl}$ & $\begin{array}{l}\text { type I predominance } \\
80 \%\end{array}$ \\
\hline 10 & $\mathrm{nl}$ & $82 / 65 / 75$ & nl & $\mathrm{nl}$ \\
\hline 11 & $\mathrm{nl}$ & $45 / 55 / 50$ & nl & nl \\
\hline 12 & $\mathrm{nl}$ & $11 / 22 / 18$ & $\mathrm{nl}$ & $\mathrm{nl}$ \\
\hline 13 & $\mathrm{nl}$ & $55 / 40 / 48$ & nI & $\mathrm{nl}$ \\
\hline 14 & nl & $396 / 270 / 300$ & $\mathbf{M}$ & $\begin{array}{l}\text { necrosis } \\
\text { hyaline degeneration } \\
\text { connective tissue }\end{array}$ \\
\hline
\end{tabular}

nl, normal; $M$, myopathic. $C K$ : exam made in three different times. 


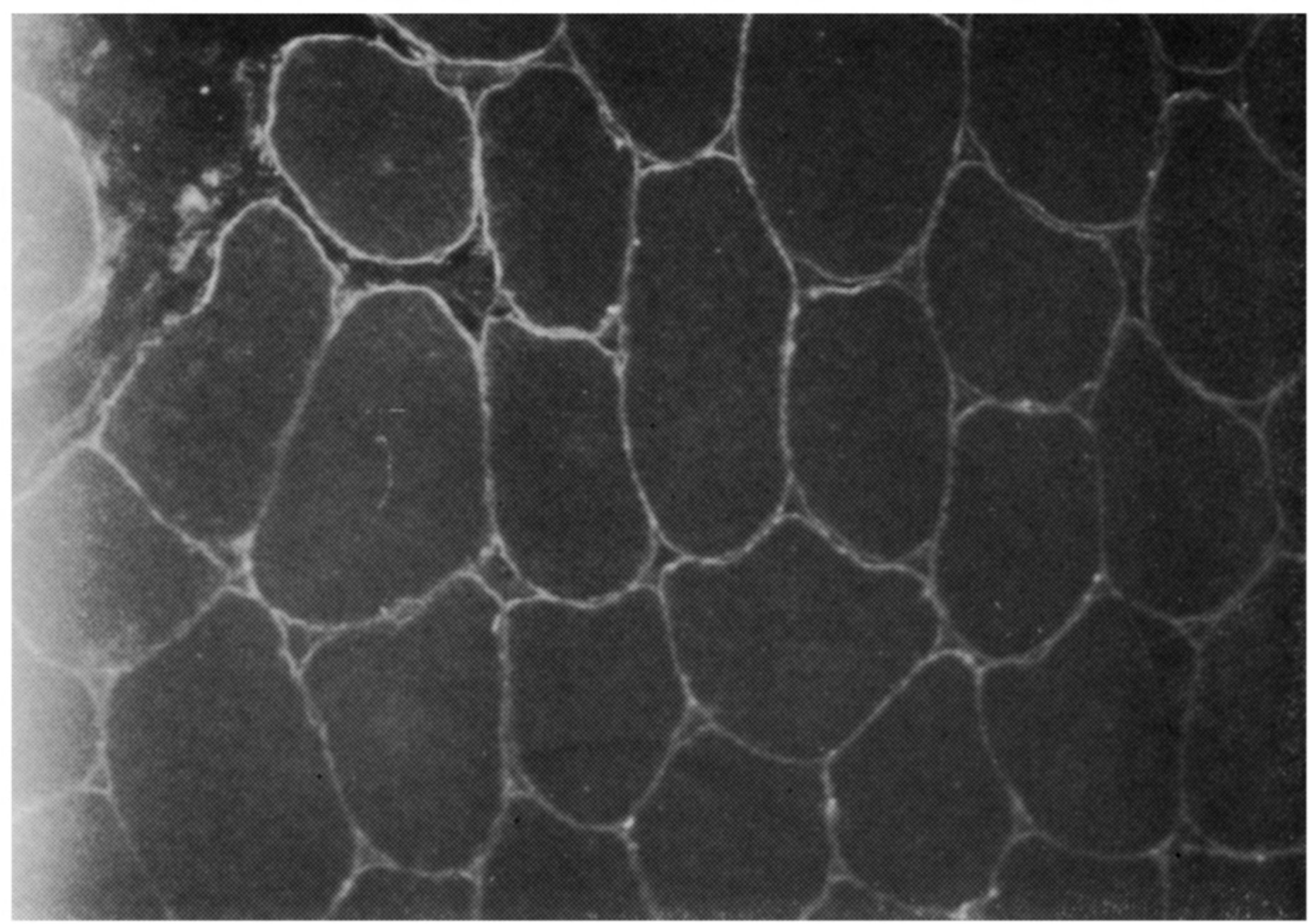

Fig. 1. The cell surface of each muscle fiber shows a normal thin and continuous layer of dystrophin immunofluorescence. $\times 200$.

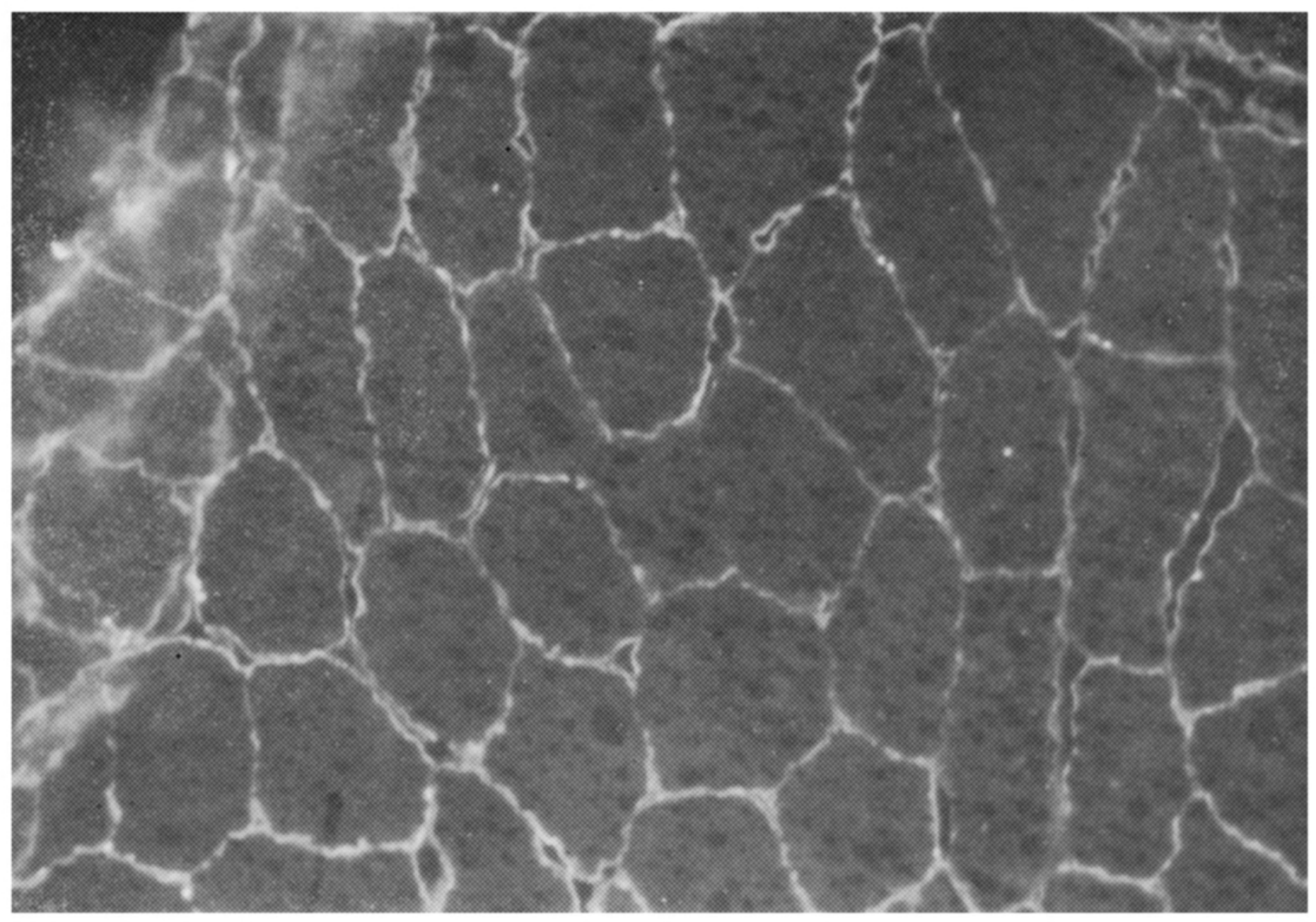

Fig. 2. Binding of anti-dystrophin in a section from one asymptomatic carrier. Lack of immunostaining in muscle fibers isolatedly disposed. $\times 260$. 


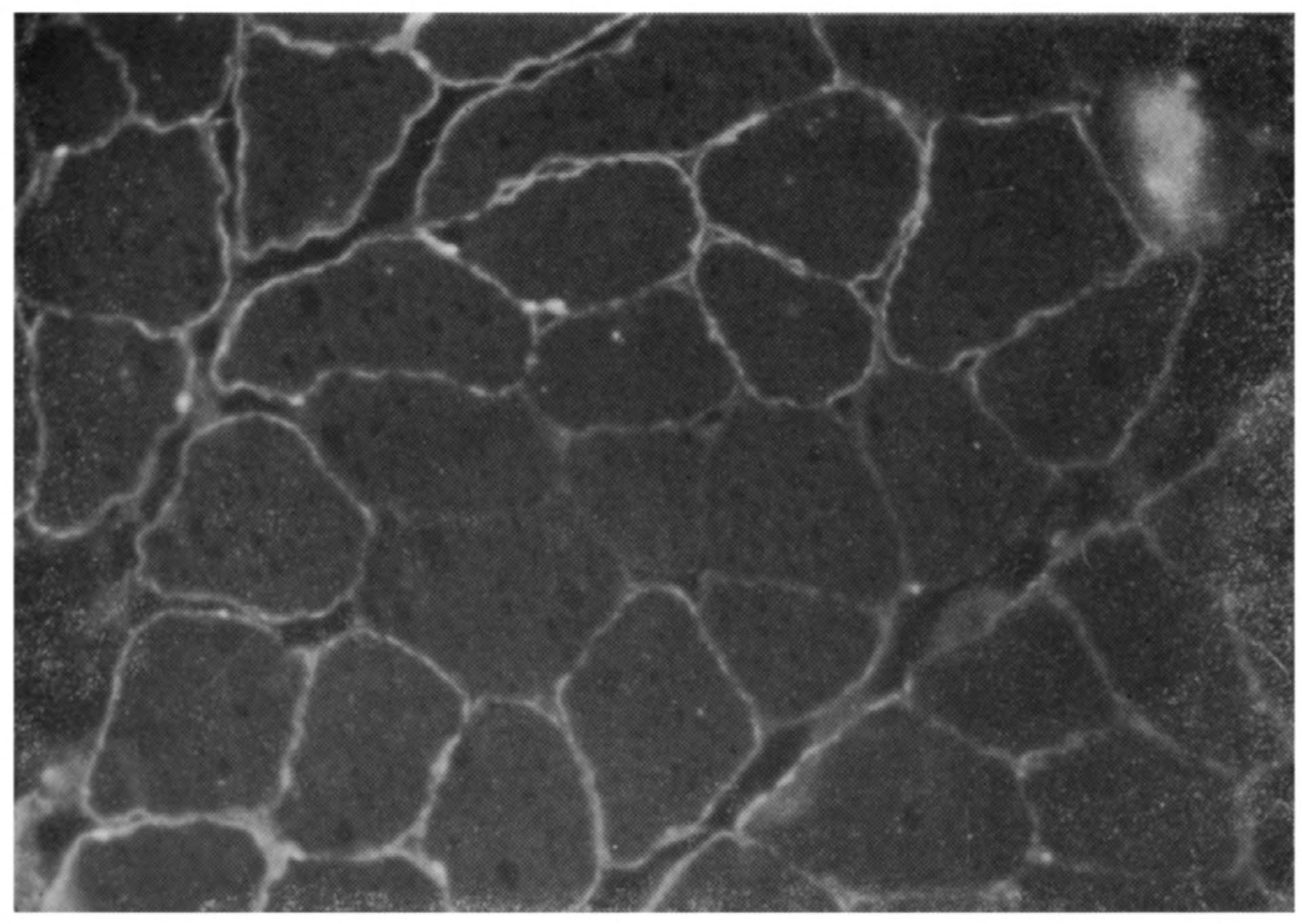

Fig. 3. Binding of anti-dystrophin in a section from one manifesting carrier (Case 5). Immuncstaining reduced in groups of muscle fibers. $\times 200$.

Table 3. Results with different diagnostic methods.

\begin{tabular}{lll}
\hline Method & $\begin{array}{c}\text { Number of } \\
\text { positive cases }\end{array}$ & Frequency \\
\hline Neurol. exam & 5 & $35.7 \%$ \\
$\quad$ calf enlargement & 2 & $14.2 \%$ \\
$\quad$ weakness & 7 & $50.0 \%$ \\
CK & 4 & $28.6 \%$ \\
EMG & 4 & $28.6 \%$ \\
Muscle biopsy & 6 & $42.8 \%$ \\
Dystrophin & &
\end{tabular}

Table 4. Results with different diagnostic methods.

\begin{tabular}{lll}
\hline & $\begin{array}{c}\text { Number of } \\
\text { positive cases }\end{array}$ & Frequency \\
\hline \hline CK and EMG & 7 & $50.0 \%$ \\
CK, EMG and muscle biopsy & 7 & $50.0 \%$ \\
CK, EMG, muscle biopsy, dystrophin & 8 & $57.1 \%$ \\
\hline
\end{tabular}


Table 5. Comparison of the results with different methods.

\begin{tabular}{ccccccc}
\hline Case & $\begin{array}{c}\text { Calf } \\
\text { enlargement }\end{array}$ & Weakness & CK & EMG & $\begin{array}{c}\text { Muscle } \\
\text { biopsy }\end{array}$ & Dystrophin \\
\hline \hline 1 & - & - & + & + & + & + \\
2 & - & - & - & - & - & + \\
3 & + & + & + & + & + & + \\
4 & - & - & + & - & - & + \\
5 & + & + & + & + & + & + \\
6 & - & - & + & - & - & - \\
7 & - & - & - & - & - & - \\
8 & - & - & - & - & - & - \\
9 & - & - & - & - & - & - \\
10 & - & - & + & - & - & - \\
11 & + & - & - & - & - & - \\
12 & + & - & - & - & - & - \\
13 & - & - & - & - & + & + \\
14 & + & - & + & + & + & \\
\hline
\end{tabular}

Table 6a. Dystrophin $\times$ Clinical examination.

Dystrophin

$+$

Clinical examination:

$\begin{array}{lccc}\text { calf enlargement } & + & 3 & 2 \\ \text { weakness } & - & 3 & 6 \\ & + & 2 & 0 \\ & - & 4 & 8\end{array}$

Table 6b. Dystrophin $\times$ Serum CK levels.

\begin{tabular}{llll}
\hline & & \multicolumn{3}{c}{ Dystrophin } \\
& & + & - \\
CK & + & 5 & 2 \\
& - & 1 & 6 \\
\hline
\end{tabular}

Table 6d. Dystrophin $\times$ Muscle biopsy.

\begin{tabular}{lccc}
\hline & \multicolumn{3}{c}{ Dystrophin } \\
& & + & - \\
Muscle biopsy & + & 4 & 0 \\
& - & 2 & 8 \\
\hline
\end{tabular}

Table 6c. Dysthophin $\times$ EMG.

\begin{tabular}{cccc}
\hline & & \multicolumn{3}{c}{ Dystrophin } \\
& & + & - \\
EMG & + & 4 & 0 \\
& - & 2 & 8 \\
\hline
\end{tabular}

Table 6e. Dystrophin $\times$ Traditional methods.

\begin{tabular}{rccc}
\hline & \multicolumn{3}{c}{ Dystrophin } \\
& & + & - \\
Traditional & + & 5 & 2 \\
methods & - & 1 & 6 \\
\hline
\end{tabular}




\section{COMMENTS}

Immunohistochemistry with dystrophin allowed us to make the diagnosis of definite DMD and BMD carrier status in women with a familial history of DMD or BMD.

The findings consisted of decreased in the immunostaining at the sarcolemma of the muscle fibers isolatedly disposed in 3 patients, and a marked reduction in the immunostaining in groups of muscle fibers in other 3 . The immunostaining with dystrophin in our cases did not show differences between type I and II fibers, suggesting that pattern expression of dystrophin is similar in the two types of muscle fibers.

We found two populations of muscle fibers in the carriers, one containing normal dystrophin and another with dystrophin deficiency. The proportion of deficiency of dystrophin was higher in two manifesting carriers of DMD than in other three asymptomatic carriers. Various clinical, histological and biochemical manifestations in carriers have been explained in terms of the Lyon hypothesis". Our findings do not contradict this assumption.

If a DMD carrier has few dystrophin-deficient fibers, she may have only subclinical muscular dystrophy, whereas if she has numerous defective fibers, she may be a manifesting carrier.

The immunohistochemmical pattern in the asymptomatic BMD carrier, with numerous defective fibers, was indistinguishable from that seen in two manifesting carriers of DMD. It is possible that in this patient the structural dystrophin alteration was not severe enough to allow the disruption of the fibers and consequent weakness, but was enough to be detected by the anti-dystrophin antibody we used. A similar phenomenon has recently been reported in a family 5 .

The comparison of the results between dystrophin immunohistochemistry with other traditional methods for the detection of DMD and BMD carriers has shown:

(1) Calf enlargement was not a good sign to make the diagnosis of definite carrier. Three cases with dystrophin-deficient fibers did not have calf enlargement, and two cases with calf enlargement had normal dystrophin immunostain in muscle fibers (Table 6a).

(2) The serum CK level was more sensitive for detecting the carrier state than dystrophin immunohistochemistry (Table 6b).

(3) Dystrophin immunohistochemistry was more sensitive than EMG and muscle biopsy with histochemistry. All cases that had myopathic changes in these exams showed dystrophin-deficient fibers, and two cases with dystrophin-deficient fibers had normal EMG and muscle biopsy (Tables $6 \mathrm{c}$ and $6 \mathrm{~d}$ ).

(4) The arrangement of CK, EMG, and muscle biopsy allowed us to detect 8 carriers of DMD and BMD out of 14. The use of dystrophin immunohistochemistry improved the accuracy of the genetic counseling. One case, that was not discriminated as a carrier using traditional methods, showed dystrophin-deficient fibers, allowing us to identify the carrier state in this case (Tables 5 and 6e).

(5) One woman, case 10, with three sons with DMD, that could be classified as obligatory carrier did not show any change in the immunostaining with dystrophin. This result can be interpreted as a false negative. In our previous publication!, one obligatory carrier also did not show any dystrophin deficiency. They may be gonadal DMD carriers rather than somatic.

Two of our patients were found to be DMD carriers only after the demonstration of dystrophin-deficient fibers in their muscle biopsies. They were referred to us with the clinical diagnosis of limb-girdle muscular dystrophy (LGD) and spinal muscular atrophy (SMA). The differential diagnosis between a manifesting heterozygote for DMD or BMD and a female case of LGD, both with the same prevalence in the general population $*>$ is of great importance, because of different genetic counseling in these conditions ${ }^{12}$. 


\section{REFERENCES}

1. Bonilla E, Schmidt B, Samitt CE, Miranda AF, Hays AP, Oliveira ASB, Chang HW, Servidei S, Ricci E, Younger DS, DiMauro S. Normal and dystrophin deficient muscle fibers in carriers of the gene for Duchenne muscular dystrophy. Am J Pathol 1988, 133: 440-445.

2. Comi G, Comola M, Galardi G. Piattoni F, Erembourg L, Canal N. Individuazione delle portatrici della distrofia muscolare di Duchenne: problemi e prospective. Minerva Pediat 1986, 38:625-632.

3. Dubowitz V, Brooke M. Muscle biopsy: a modern approach. London: W.B. Saunders, 1973.

4. Emery ASH. The muscular dystrophies. In Emery AEH, Rimoin D (eds): Principles and Practice of Medical Genetics. Edinburgh: Churchill Livingstone, 1983, p 332-411.

5. England SB, Nicholson LVB, Johnson MA, et al. Very mild muscular dystrophy associated with deletion of $46 \%$ of dystrophin. Nature 1990, 343:180-182

6. Gutmann DH, Fischbeck KH. Molecular biology of Duchenne and Becker's muscular dystrophy: clinical applications. Ann Neurol 1989, 26:189-190.

?• Kendal HO, Kendal FP, Wadsworth GE. Muscle testing and function. Ed 2. Baltimore: Williams ?and Wilkins, 1971.

8. Lyon MF. Sex chromatin and gene action in the mammalian X-chromosome. Am J Human Genet 1962, 14:135-148.

9. Milhorat AT, Goldstone L. The carrier state in muscular dystrophy of the Duchenne type: identification by serum creatine-kinase level. JAMA 1965, 194:130-134.

10. Yates JRW, Emery AEH. A population study of adult onset limb-girdle muscular dystrophy. J Med Genet 1985, 22:250-257.

11. Werneck LC, Bonilla E. Distrofina na diferenciação das distrofias de Duchenne e Becker: estudo imuno-histoquímieo comparado com o estadio clínico, enzimas séricas e biópsia muscular. Arq Neuro-Psiquiatr 1990, 48:454-464.

12. Zellweger H, Ionasescu V, Simpsom J. Sporadic Duchenne muscular dystrophy in females: genetic counseling of 'women with pelvifemoral muscular dystrophy. Helvet Paed Acta 1980, 35:343-348. 